\title{
Alexander Marchant (1912-1981)
}

Brazilian history in the U.S. lost one of its pioneers on October 8, 1981, with the death of Professor Alexander Marchant at Vanderbilt University Hospital in Nashville, Tennessee. Born in Rio de Janeiro in 1912 of an American father and an English mother, Marchant took his B.A. at National University in 1931, his M.A. at American University in 1933, received his doctorate at Johns Hopkins University in 1941 where he also served as Instructor from 1938 to 1940 . He joined the Department of State in the latter year as Research Associate and continued with the Department until 1947, when he was appointed Associate Professor of History at Vanderbilt. He was promoted to Professor in 1951, was the first recipient of the University's Chancellor's Cup in 1963, an award "... for outstanding contributions to student-faculty relations outside the classroom...," and retired Professor Emeritus in September, 1978.

His major publications include the seminal From Barter to Slavery: The Economic Relations of Portuguese and Indians in the Settlement of Brazil, 1500-1580 (Johns Hopkins University Press, 1942, Reprinted by Peter Smith, 1966); Boundaries of the Latin American Republics: An Annotated List (U.S. Government Printing Office, 1942, 1944); Editor, with T. Lynn Smith, Brazil: Portrait of Half a Continent (Dryden Press, 1951, Reprinted by Greenwood Press, 1972); and Editor, Proceedings of the International Colloquium on LusoBrazilian Studies (Vanderbilt University Press, 1953).

Professor Marchant served as Associate Managing Editor of the Hispanic American Historical Review from 1950 to 1953, was Secretary-Treasurer of the Conference on Latin American History, 1951-1952, and was elected its Chairman in 1953. In 1952 he was a Social Science Research Fellow and was honored in that same year with the Order of the Southern Cross by the Government of Brazil.

Vanderbilt University

J. Leon Helguera

Nashville, Tennessee 